\title{
Prioritization of Land Consolidation Interventions in the Villages of Central Poland
}

\author{
Przemysław Leń ${ }^{1 *}$, Karol Noga' ${ }^{1}$ \\ 1 Department of Environmental Engineering and Geodesy, University of Life Sciences in Lublin, Poland \\ * Corresponding author's e-mail: przemyslaw.len@up.lublin.pl
}

\begin{abstract}
Re-structuring of rural spaces is essential for continued sustainable development of these areas. The space-management tool of land consolidation can be used to obtain desirable structural changes, but only if it is systematically implemented and becomes a permanent element of long-term rural management policies of provincial self-governments. Land consolidation and exchange measures should be introduced comprehensively and should be coupled with post-consolidation development of land. Only then can they contribute to the multifunctional development of rural areas. In our previous studies, in order to identify the areas with the greatest defects in the spatial structure which needed land consolidation and exchange most urgently, we carried out the investigations which allowed us to select appropriate factors for identifying such groups of villages. The ranking was established using Hellwig's synthetic index of development and the zero unitarisation method. This article presents the results of the research carried out in 36 villages of the Opoczno commune, occupying a total area of 16,590.51 ha, divided into 41,990 cadastral plots.
\end{abstract}

Keywords: land consolidation, rural areas, defective spatial structure of agricultural land, prioritization ranking for land adjustment

\section{INTRODUCTION}

The spatial layout of contemporary villages results from centuries of human activity. In order to provide livelihoods for themselves, people have been changing the natural landscape by adjusting it to their own needs, disregarding the negative effects of their activity. Settlement had a decisive impact on changing the structure of villages, contributing to the division of inhabited areas according to specific rules. As a result of this division, various forms of land use have developed. One consequence of economic development of rural society included continuous transformations of land structure, the rate of which was influenced by the stage of the development and economic conditions [Noga 2001].

In each area there are various objects, characterized by specific structures, which altogether create a broadly defined spatial structure. This structure encompasses spatial and natural objects, as well as those which have been created as a re- sult of human activity. Unfortunately, the spatial structure of Polish villages seems to become more and more disadvantageous. This is a consequence of many instances of negligence, regarding ownership and economic relations, which have exerted a negative influence on agriculture and its development. Due to the high costs of land consolidation, it is necessary to prepare an analysis of land structure [Żak 2006] before measures are introduced to manage and use agriculturally useless areas, commonly referred to as problem areas of agriculture, in an alternative way [Wójcik-Leń and Sobolewska-Mikulska 2017a, 2017b].

A characteristic feature of agriculture in central Poland is excessive land fragmentation and scattering, as well as an unfavorable geometry of parcels. These factors impede profitable agricultural production. Additionally, the existing network of roads of direct access to fields does not allow for the transport of modern agricultural machines. Combined, these facts show that villages of central Poland require consolidation measures aimed at improving 
the parameters of the spatial structure of land [Dawidowicz and Zrobek 2014, 2016]. This problem pertains also to other regions of Poland. Substantial defects are found in the farmland located in the eastern [Stręk 2017] and south-eastern [Kwinta and Gniadek 2017, Wójcik-Leń and Stręk 2017] parts of Poland. The defective spatial structure of these areas impedes the process of creating a full-featured real estate cadastre [Mika 2016, 2017].

The law defines consolidation in the following way [Act 1982]: a land adjustment measure, aiming at transformation of the spatial structure of lands located in rural areas in such a way as to create more favourable conditions for farming by improving the land-distribution structure of agricultural holdings and distribution of parcels in holdings, as well as by adjusting parcel boundaries to the existing water drainage systems, roads, and topography. The Rural Development Programme [RDP 2014] for the years 2014-2020, describes land consolidation as a measure that involves: the creation of new land parcels, having a different layout than the original ones, with a view to reducing the number of small, scattered parcels that make up a holding, and increasing their average size. As part of a consolidation project, land management activities are also conducted after land consolidation, which include the creation of a functional network of access roads to farming and forestry land and the regulation of hydrological regime in the consolidated area. Land consolidation results in new organization of agricultural holdings, and improves the land structure coefficient by decreasing the number of plots, increasing their area, reducing the distance between the plots and the farmstead, and changing the irregular shape of plots.

The objective of this article was to establish a prioritization ranking of land consolidation and exchange interventions for 29 villages of the Opoczno commune, located in the Łódź Voivodeship. The research area covered $12,384.55$ ha of farmland divided into 15,652 land parcels (cadastral plots).The ranking list was created using Hellwig's synthetic index of development and the zero unitarisation method (ZUM). The calculations were based on data gleaned from the real cadastre database of the District Office of Opoczno. On the basis of an algorithm for selecting groups of factors for the purpose of land consolidation prioritization in rural areas [Leń 2018], appropriate factors were selected, taking into consideration the specific features of the examined area.

\section{CHARACTERISTICS OF SELECTED FACTORS}

The first stage of the study involved selecting the factors which characterized the spatial structure of the area, studied at three levels of specificity. For this purpose, we used an algorithm developed by Leń [2018] for selecting groups of factors for prioritization of land consolidation in rural areas.

The first specificity level consists of general factors, specific factors, access to roads, and agricultural productivity ratio. General factors communicate the most important information about the analysed objects. The information is derived from cadastral databases and includes: $\mathrm{Gx}_{1}$ - total area of the precinct [ha], $\mathrm{Gx}_{2}-$ total number of plots in the precinct, $\mathrm{Gx}_{3}-$ number of residents, $\mathrm{Gx}_{4}$ - number of residents per 1 $\mathrm{km}^{2}, \mathrm{Gx}_{5}$ - percentage of the area of land owned by individual farmers, $\mathrm{Gx}_{6}$ - percentage of the area of plots owned by individual farmers, $\mathrm{Gx}_{7}$ - average area of the plot in the village [ha]. The second significant group of factors, classified as the first level of data specificity, involves specific factors significantly supplementing the information about private lands. These include: $\mathrm{PLx}_{1}$ - number of registration units in the precinct, $\mathrm{PLx}_{2}-$ number of registration units of farms, $\mathrm{PLx}_{3}-$ percentage of registration units of farms, $\mathrm{PLx}_{4}$ - number of registration units of land which does not form part of farms, $\mathrm{PLx}_{5}$ percentage of registration units of land which do not form part of farms, $\mathrm{PLx}_{6}$ - number of plots per registration unit of farms, $\mathrm{PLx}_{7}$ - area of plots owned by farms [ha], $\mathrm{PLx}_{8}$ - percentage of the number of plots owned by farms in relation to all private lands, $\mathrm{PLx}_{9}$ - percentage of the area of plots in relation to all private lands, $\mathrm{PLx}_{10}$ - average number of plots per registration unit, $\mathrm{PLx}_{11}$ - average area of a registration unit (ha). The third group of factors refers to the plots without the direct access to agricultural transport roads: $\mathrm{Rx}_{1}-$ percentage of the number of plots without access to roads and $\mathrm{Rx}_{2}$ - percentage of the area of plots without access to roads. The fourth group of factors refers to agricultural productivity ratio: $\mathrm{APx}_{1}$ - cropland productivity ratio, $\mathrm{APx}_{2}-$ grassland productivity ratio. The above-mentioned ratios were calculated based on the factors conveying information about the area of cropland and grassland (meadows, pastures) as well as their soil classes. 
The selection of factors at the second level of data specificity depends on the geographical situation of the analysed territory. Therefore, the second level of specificity of data includes (wholly or optionally, depending on the survey area) information about fragmentation of the farms' land identified as: (area) $\mathrm{Ax}_{1}$ - average plot area (ha). For the purposes of more specific analysis of fragmentation, we calculated the synthetic land fragmentation index: $\mathrm{LFx}_{1}$ - synthetic index of fragmentation and shape of plots in the analyzed villages: $\mathrm{Sx}_{1}$ - average value of the plot shape index, $\mathrm{Sx}_{2}-$ synthetic plot shape index.

The third level of specificity of factors characterizes the analysed area in terms of the effectiveness and project potential during land consolidation works. At this level, detailed analyses concerning the ownership structure and land use characteristic of the analysed village are carried out. The structure of ownership is composed of the following factors: $\mathrm{OSx}_{1}$ - percentage of land owned by the Agricultural Property Agency of the State Treasury, $\mathrm{OSx}_{2}$ - percentage of land owned by the State Forests, $\mathrm{OSx}_{3}$ - percentage of land owned by communities, $\mathrm{OSx}_{4}$ - percentage of land owned by cooperatives, $\mathrm{OSx}_{5}$ - percentage of land owned by churches and religious associations, $\mathrm{OSx}_{6}$ - percentage of land owned by land communities, $\mathrm{OSx}_{7}$ - percentage of land owned by powiats. The selection of factors takes into account only certain forms of ownership (registration groups) listed in the regulation concerning the land and buildings register [Regulation 2013]. The percentage of other forms of ownership in most cases does not occur in rural areas, so it can be neglected at this stage of the analysis. It is common knowledge that the effects of land consolidation works depend on the existing conditions characteristic of the specific object. If the object is characterized by a large number of elements that cannot be replaced, so-called 'project invariants', the potential deliverable of project works is considerably smaller than for the objects without such limitations. Therefore, it is necessary to analyse the structure of use for which identification was adopted according to groups of land specified in the regulation concerning land and buildings register [Regulation 2013]. This group also comprises the following factors: $\mathrm{LUx}_{1}$ - percentage of orchards $-\mathrm{S}, \mathrm{LUx}_{2}$ - percentage of built-up agricultural land - $\mathrm{Br}$, $\mathrm{LUx}_{3}$ - percentage of cropland with trees and shrubs - Lzr, $\mathrm{LUx}_{4}$ - percentage of pond bot- toms $-\mathrm{Wsr}, \mathrm{LUx}_{5}-$ percentage of ditch bottoms $-\mathrm{W}, \mathrm{LUx}_{6}-$ percentage of wasteland $-\mathrm{N}, \mathrm{LUx}_{7}$ - percentage of forestland - Ls, $\mathrm{LUx}_{8}$ - percentage of land with trees and shrubs $-\mathrm{Lz}, \mathrm{LUx}_{9}-$ percentage of housing area $-\mathrm{B}, \mathrm{LUx}_{10}$ - percentage of industrial area $-\mathrm{Ba}, \mathrm{LUx}_{11}$ - percentage of other built-up land $-\mathrm{Bi}, \mathrm{LUx}_{12}$ - percentage of urbanized land without buildings or under building development $-\mathrm{Bp}, \mathrm{LUx}_{13}$ - percentage of leisure grounds $-\mathrm{Bz}, \mathrm{LUx}_{14}$ - percentage of surface mining land in use $-\mathrm{K}, \mathrm{LUx}_{15}$ - percentage of roads - dr, $\mathrm{LUx}_{16}$ - percentage of railway grounds - Tk, $\mathrm{LUx}_{17}$ - percentage of other transport grounds $-\mathrm{Ti}, \mathrm{LUx}_{18}$ - percentage of land for the construction of public roads or railway lines - $\mathrm{Tp}, \mathrm{LUx}_{19}$ - percentage of ecological land - E-R, E- - , E-Ps, E-Ls, E-Lz, E-Lzr, E-Wp, E-Ws, E-N, LUx $x_{20}$ - percentage of bottoms of internal seawaters - Wm, $\mathrm{LUx}_{21}$ - percentage of bottoms of flowing surface waters $-\mathrm{Wp}, \mathrm{LUx}_{22}$ - percentage of bottoms of still surface waters - Ws, $\mathrm{LUx}_{23}$ - percentage of various lands - Tr [Leń 2018].

In Figure 1, the colour red was used to mark the set of factors at each of the three levels of specificity selected for the Poświętne commune (central Poland) on the basis of the universal algorithm.

The resulting group of factors at three levels of specificity characterizing the analysed area at a further stage of works will be subject to a statistical analysis, since multi-dimensional statistical methods that aid in determining the synthetic measures are helpful in the analyses concerning the urgency of land consolidation and exchange works and, in particular, in the comparative spatial analyses. Synthetic measures replace the numerous set of features of the analyzed object with a single aggregate variable, thanks to which the analyzed villages can be ordered according to the urgency of land consolidation and exchange works being under consideration. Therefore, a ranking of urgency of land consolidation works has been designed.

\section{Prioritization of demand for land consolidation works}

The ranking of urgency of land consolidation and exchange works was made for all the 36 villages of the Opoczno commune, on the basis of Hellwig's synthetic index of development and the zero unitarisation method. 


\section{DATA SPECYFICITY LEVEL I}

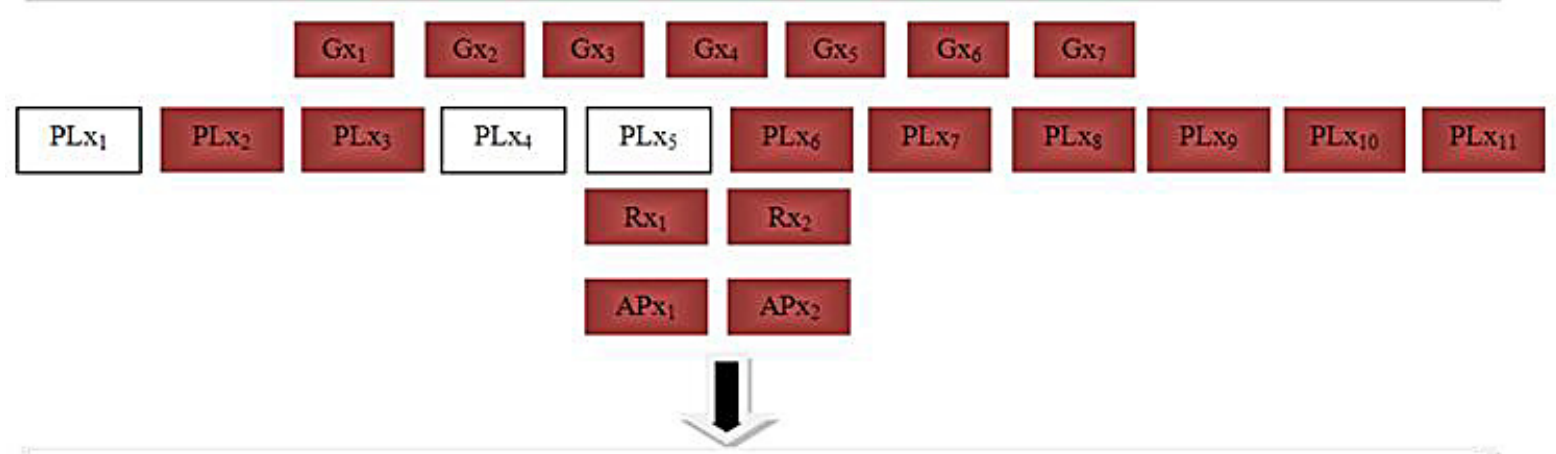

\section{DATA SPECYFICITY LEVEL II}

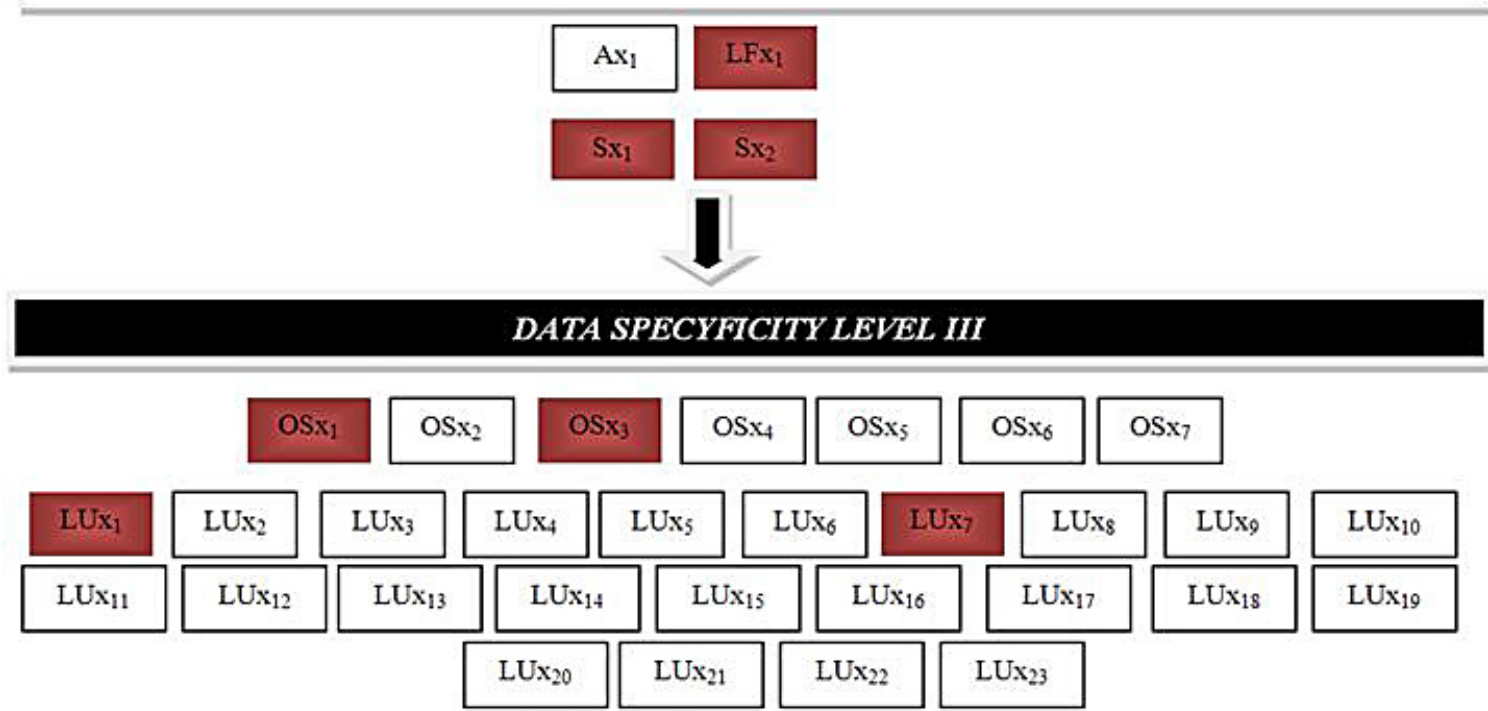

Figure 1. Specification of factors at three specificity levels

First, Hellwig's synthetic index of development was calculated. The advantage of this method, which had been applied in earlier research [Leń et al. 2017], is the fact that it integrates various factors and assigns a complex aggregate measure to them. This measure allows a thorough comparison of items under analysis [Adamowicz and Janulewicz 2012].

In the first stage of calculations, the reference object with standardized variables is established:

$$
\mathbf{O}_{0}=\left\lfloor z_{o j}\right\rfloor, j=1,2, \ldots, m \text {. }
$$

The reference object has coordinates, which can be obtained using the formula:

$z_{o j}=\max \left\{z_{i j}\right\}-$ when the selected feature is a stimulant, ${ }^{i}$

$z_{o j}=\min \left\{z_{i j}\right\}-$ when the selected feature is a destimulant.

For the features obtained in this study, a reference-object-based method was used which assumes that there is a reference object, with reference to which the taxonomic distances of the objects being analyzed are established. In order to calculate these distances, the Euclidean metric is used:

$$
d_{i 0}=\left[\sum_{j=1}^{m}\left(z_{i j}-z_{0 j}\right)^{2}\right]^{\frac{1}{2}} i=1,2, \ldots, m
$$

where $d_{i}$ values are subsequently used in order to calculate Hellwig's synthetic development index:

where:

$$
s_{i}=1-\frac{d_{i 0}}{d_{0}} i=1,2, \ldots, m
$$

$$
d_{0}=\bar{d}_{0}+2 S\left(d_{0}\right)
$$

with:

$$
\bar{d}_{0}=\frac{1}{n} \sum_{i=1}^{n} d_{i 0} ; S\left(d_{0}\right)=\left[\frac{1}{n} \sum_{i=1}^{n}\left(d_{i 0}-\bar{d}_{0}\right)^{2}\right]^{\frac{1}{2}}
$$

Parameter $S_{i}$ usually has values in the range $<0 ; 1>$. The more the $S_{i}$ value approximates unity, the more similar it is to the reference object. 
The results of the calculations performed using Hellwig's method were compared to those obtained with the zero unitarisation method. According to Kukuła [2012], diagnostic variables of objects can be classified as stimulants, destimulants, and nominants.

Stimulants are the variables whose increase in value contributes to an increase in the value of a diagnostic feature of the object under consideration. According to the zero unitarisation method, in the case of variables which are stimulants, the following formula is applied:

$$
Z=\frac{\left(x-x_{\min }\right)}{\left(x_{\max }-x_{\min }\right)}
$$

Destimulants are variables whose increase in value contributes to a decrease in the value of a diagnostic feature of the object under consideration. According to the zero unitarisation method, the following formula is applied for variables which are destimulants:

$$
Z=\frac{\left(x_{\max }-x\right)}{\left(x_{\max }-x_{\min }\right)}
$$

where: $z$-standardized variable,

$x$ - variable before standardization,

$x_{\max }$ - maximum value of a variable in a given set, $x_{\min }-$ minimum value of a variable in a given set.

Thanks to the standardization of diagnostic features, we can obtain a consolidated multi-criterial evaluation of each object. It is possible to obtain one consolidated evaluation of these objects by means of aggregation. In order to calculate the synthetic measure, it is necessary to establish average values of sets which characterize individual features, on the basis of the formula given below [Pluta 1986]:

$$
z_{i}=\frac{1}{p} \sum_{i=1}^{p} x_{i j}(i=1, \ldots, m)
$$

The standardized measures have values in the range $<0 ; 1>$. The results can be regarded as mean values of optimal values for each object. Consequently, the higher the value of the synthetic measure, the higher the position of a given object in the ranking list [Mika 2016].

The values of synthetic measures obtained in the study were used to create a prioritization ranking for the Opoczno commune, showing which villages of the commune needed consolidation most urgently. Two independent ranking lists are shown in Table 1, and a spatial map of location of the villages is presented in Figures 2 and 3.

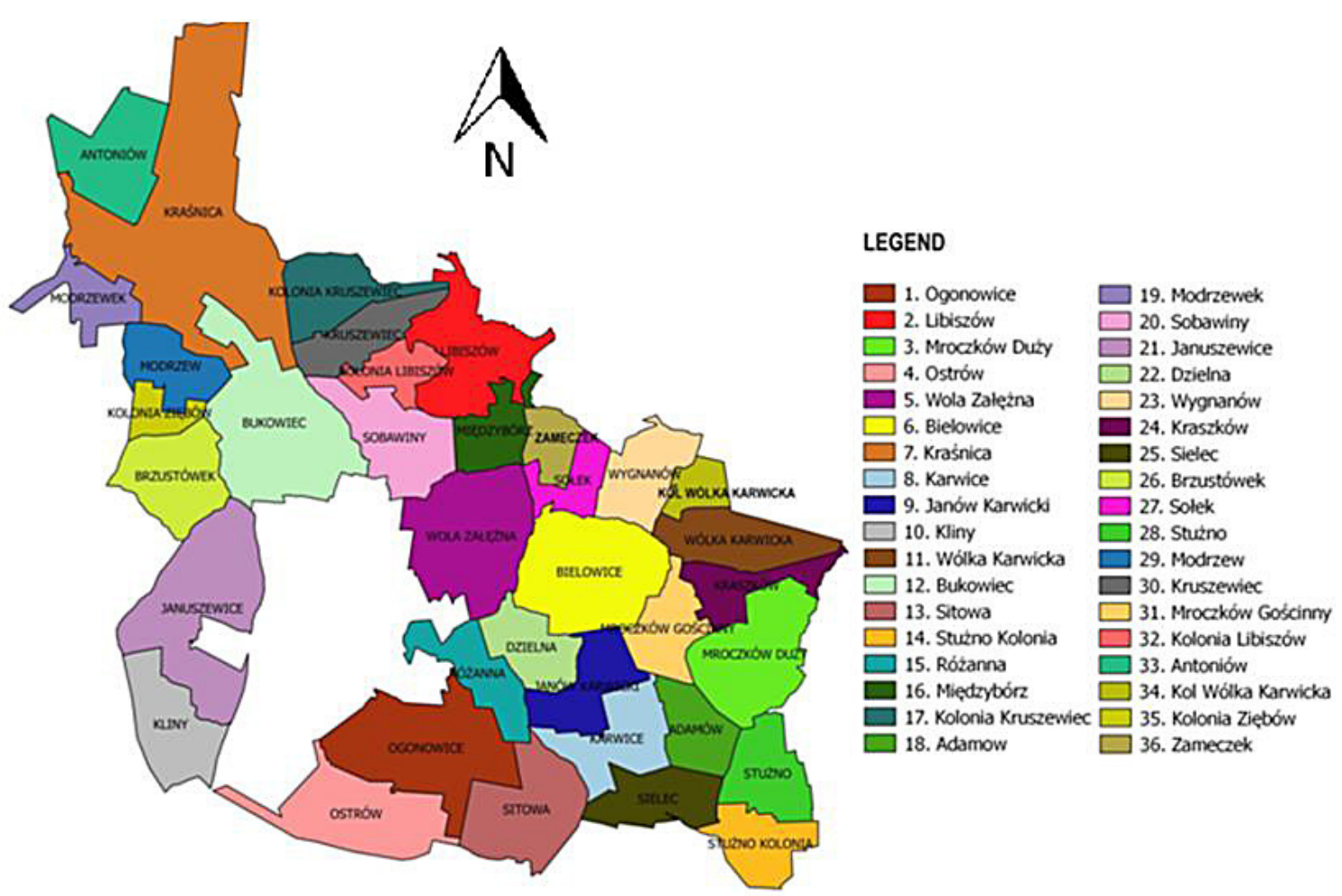

Figure 2. A ranking of urgency of land consolidation and exchange, prepared using Hellwig's synthetic index of development 
Table 1. Land consolidation urgency rankings obtained using ZUM and Hellwig's method

\begin{tabular}{|c|c|c|c|c|}
\hline \multirow{2}{*}{$\begin{array}{l}\text { Position on the } \\
\text { ranking list }\end{array}$} & \multicolumn{2}{|c|}{ Hellwig's synthetic index of development } & \multicolumn{2}{|c|}{ Zero unitarisation method } \\
\hline & $\begin{array}{l}\text { Value of the synthetic } \\
\text { measure }\end{array}$ & $\begin{array}{l}\text { Name of cadastral } \\
\text { community }\end{array}$ & $\begin{array}{l}\text { Value of the synthetic } \\
\text { measure }\end{array}$ & $\begin{array}{c}\text { Name of cadastral } \\
\text { community }\end{array}$ \\
\hline 1 & 0.78 & Ogonowice & 0.61 & Ogonowice \\
\hline 2 & 0.66 & Libiszów & 0.58 & Bielowice \\
\hline 3 & 0.56 & Mroczków Duży & 0.55 & Libiszów \\
\hline 4 & 0.49 & Ostrów & 0.55 & Ostrów \\
\hline 5 & 0.49 & Wola Załężna & 0.55 & Wola Załężna \\
\hline 6 & 0.48 & Bielowice & 0.55 & Kliny \\
\hline 7 & 0.48 & Kraśnica & 0.55 & Wygnanów \\
\hline 8 & 0.46 & Karwice & 0.54 & Adamów \\
\hline 9 & 0.43 & Janów Karwicki & 0.54 & Dzielna \\
\hline 10 & 0.43 & Kliny & 0.53 & Międzybórz \\
\hline 11 & 0.38 & Wólka Karwicka & 0.53 & Mroczków Duży \\
\hline 12 & 0.35 & Bukowiec & 0.53 & Karwice \\
\hline 13 & 0.35 & Sitowa & 0.53 & Modrzew \\
\hline 14 & 0.33 & Stużno Kolonia & 0.53 & Janów Karwicki \\
\hline 15 & 0.31 & Różanna & 0.52 & Stużno Kolonia \\
\hline 16 & 0.31 & Międzybórz & 0.52 & Kraśnica \\
\hline 17 & 0.31 & Kolonia Kruszewiec & 0.51 & Wólka Karwicka \\
\hline 18 & 0.30 & Adamów & 0.51 & Sołek \\
\hline 19 & 0.28 & Modrzewek & 0.51 & Sobawiny \\
\hline 20 & 0.27 & Sobawiny & 0.50 & Kolonia Libiszów \\
\hline 21 & 0.27 & Januszewice & 0.50 & Brzustówek \\
\hline 22 & 0.25 & Dzielna & 0.47 & Kruszewiec \\
\hline 23 & 0.24 & Wygnanów & 0.47 & Kolonia Kruszewiec \\
\hline 24 & 0.22 & Kraszków & 0.47 & Kraszków \\
\hline 25 & 0.22 & Sielec & 0.47 & Bukowiec \\
\hline 26 & 0.22 & Brzustówek & 0.46 & Różanna \\
\hline 27 & 0.21 & Sołek & 0.46 & Stużno \\
\hline 28 & 0.20 & Stużno & 0.46 & Kol Wólka Karwicka \\
\hline 29 & 0.20 & Modrzew & 0.46 & Sitowa \\
\hline 30 & 0.20 & Kruszewiec & 0.45 & Januszewice \\
\hline 31 & 0.17 & Mroczków Gościnny & 0.45 & Kolonia Ziębów \\
\hline 32 & 0.17 & Kolonia Libiszów & 0.45 & Modrzewek \\
\hline 33 & 0.17 & Antoniów & 0.43 & Mroczków Gościnny \\
\hline 34 & 0.12 & Kol Wólka Karwicka & 0.40 & Sielec \\
\hline 35 & 0.07 & Kolonia Ziębów & 0.39 & Antoniów \\
\hline 36 & 0.02 & Zameczek & 0.25 & Zameczek \\
\hline
\end{tabular}

As shown in Table 1, the positions of the following villages were the same in both rankings: Kraszków, Ogonowice, Ostrów, Wola Załężna, and Zameczek. These settlements constituted over $13 \%$ of all analyzed villages. Four locations (over $11.1 \%$ of all villages) had the ranks that differed in one position. A difference of two positions was found for Antoniów and Mroczków Gościnny, which constituted over $5 \%$ of the whole study group. The ranks of four cadastral communities (over 11\% of the villages studied) in the two lists differed by four positions. Another two villages differed by five ranking posi- tions. A difference of six positions was found in the case of four villages $(11.1 \%)$. Two communities $(5.6 \%)$ had ranks that differed by 8 positions between the two lists. A difference of 9 positions was found for four villages, which constituted $11.1 \%$ of all the villages studied. Differences of 10,11 , and 12 positions occurred in the case of Adamów (2.8\%), Różanna (2.8\%), Kolonia Libiszów $(2.8 \%)$, respectively. The ranks of three villages ( $8.3 \%$ of all villages) differed by 13 positions. The greatest discrepancy in the value of the synthetic measure between the two analyzed ranking lists was 16 positions. Such a large dif- 


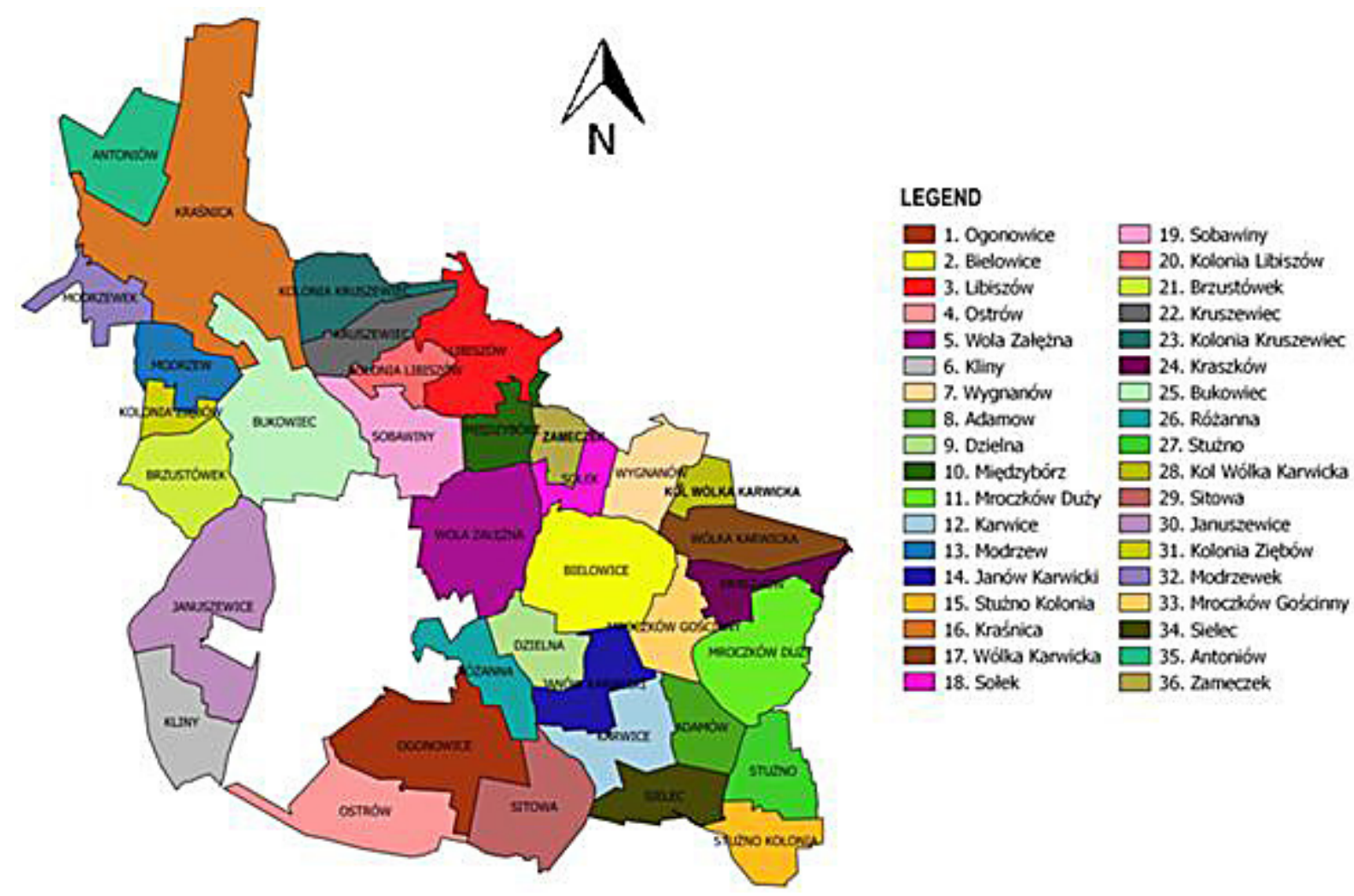

Figure 3. A ranking of urgency of land consolidation and exchange, prepared using the zero unitarisation method

ference was found for the villages of Sitowa, Modrzew, and Wygnanów.

Theresults of thepresentstudyindicatethatconsolidation is required most urgently in the villages of Ogonowice, Libiszów, Bielowice, Ostrów, and Wola Załężna. These villages are characterized by a very high number of privately owned plots and a low fragmentation index. In Ostrów, plots which are part of private agricultural holdings constitute $90 \%$ of the general number of plots; in the remaining locations, the privately owned plots constitute over $90 \%$ of all plots. It needs to be noted that one of the selected locations - Libiszów - stands out as having the smallest average size of individually owned plots $(0.21 \mathrm{ha})$. This location also has a very low fragmentation index of 2.89. For comparison, the fragmentation indices for the other villages are as follows: Ogonowice - 3.11, Ostrów - 3.30, Wola Załężna -3.67 , Bielowice -3.86 .

What is worth mentioning is the fact that the percentage of the area covered by land belonging to agricultural holdings (group 7.1), in relation to group 7 , in the selected villages, is very high and amounts to over $90 \%$ for each village (Bielowice -96.8\%, Libiszów-95.7\%, Ogonowice-94.7\%, Ostrów - 96.5\%, Wola Załężna - 93.3\%).
The analysis has also shown that the villages of Ogonowice and Libiszów have the highest general number of plots in the whole commune, which amounts to 3,350 and 2,672 plots, respectively.

The villages of Bielowice, Ogonowice, and Wola Załężna have the largest populations, in relation to the whole commune. There are over 100 inhabitants per $1 \mathrm{~km}^{2}$ in those villages.

The productivity ratio for arable land in Wola Załężna, Ogonowice, Bielowice, and Libiszów is 0.4 . In Ostrów, the ratio is a bit lower at 0.3 . The situation is similar in the case of the productivity ratio for grasslands. A ratio of 0.4 was obtained for Ogonowice, Bielowice, Libiszów, and Ostrów. In the case of Wola Załężna, the ratio is 0.5 , which is the highest value in the entire commune.

Within the area of Wola Załężna, 7.1\% of plots have no road access, and in the other villages this percentage is much higher: Bielowice $-15.6 \%$, Ostrów $-28.0 \%$, Ogonowice $-30.5 \%$, and Libiszów $-40.3 \%$.

An analysis of the geometry of the plots has shown that an average value of the elongation ratio is over 2 in Bielowice, Wola Załężna, and Libiszów. In Ogonowice, the elongation ratio is 3.2, and in Ostrów only 1.3. In the case of the synthet- 
ic elongation ratio, the numbers vary among the villages. An elongation ratio of over 2 was found for Bielowice and Ogonowice, and the values for the remaining locations are: Libiszów (3.0), Wola Załężna (3.2), Ostrów (1.8).

The last position in both ranking lists is occupied by the village of Zameczek, which is the third smallest settlement in the commune. It is characterized by the lowest number of plots belonging to private agricultural holdings, which constitute $64.3 \%$ of all the plots in the area. This village has the highest fragmentation index in the whole commune, which amounts to 4.97 , and the average plot area (group 7) is 8.15 ha. The synthetic plot elongation index reaches the value of 5.2 , whereas the average elongation is 5.0. These are the highest values among of the ones obtained for the studied locations.

\section{CONCLUSIONS}

The results of the present study, which regards the prioritization of consolidation interventions in the villages of the Opoczno commune, show that the spatial structure in the analyzed area is very defective and requires major re-adjustment. In particular, land consolidation and exchange measures should be implemented in this area. These measures are used to improve the spatial structure of rural areas, but they might also have a positive effect on the acceleration of reforms aimed at transforming the Land and Property Register into a full-featured real estate cadastre in Poland.

In this light, it seems necessary to work towards the preparation and implementation of land consolidation programs. This applies both to the local government authorities and land owners, who frequently oppose the introduction of such measures. Consolidation helps to improve the spatial parameters such as the number, area and shape of plots, as well as reduce the number of plots without road access and the number of plots in individual holdings, as well as increase the width of plots. As a result of consolidation, the road network is improved, which decreases the time it takes a farmer to get to the fields. Planned rearrangement of land parcels increases the profitability of agricultural production. It is worth noting that besides improving the farming conditions, land consolidation brings additional benefits, including social gains (better living and working conditions), an increase in the mar- ket value of plots, positive changes in landscape and the environment (melioration, recultivation), organizational and legal benefits (termination of easement, co-ownership, and collective land ownership). Consolidated lands become more attractive as tourist destinations and provide more opportunities for the development of non-agricultural activity.

Because it is impossible to rearrange land parcels in a larger area all at the same time, due to financial and other considerations, the consolidation measures should first be implemented in those villages, the spatial structure of which is the most defective. Multidimensional statistics greatly facilitate establishing the order in which villages in a given area should be subjected to land consolidation and exchange.

\section{REFERENCES}

1. Adamowicz M., Janulewicz P. 2012. The use of multidimensional methods in determining the competitive position of the commune on the example of the Lubelskie Voivodeship (in Polish). Vol. XIII/1, Katedra Ekonometrii i Statystyki SGGW, Warszawa.

2. Dawidowicz A., Zrobek R. 2014. Analysis of concepts of cadastral system technological development. In: Proceedings of the 9th International Conference Environmental Engineering - Selected Papers. DOI: 10.3846/enviro.2014.201.

3. Dawidowicz A., Zrobek R. 2016. Hierarchical development of the spatial data infrastructures as a globalization trend. In: Proceedings of the Baltic Geodetic Congress, Geomatics 2016. DOI: 10.1109/BGC.Geomatics.2016.34.

4. Kukuła K. 2012. Quantitative methods in economic research. Proposal to build a ranking of objects using quantitative and qualitative features (in Polish).. Vol. XIII/1, Katedra Ekonometrii i Statystyki SGGW, Warszawa.

5. Kwinta, A., Gniadek, J. 2017. The description of parcel geometry and its application in terms of land consolidation planning. Computers and Electronics in Agriculture, 136, 117-124.

6. Leń P., Skrzypczak I., Oleniacz G., Mika M. 2017. The use of statistical methods for the evaluation of land adjustment proposals and elimination of the patchwork pattern of land ownership. In: Proceedings of the 10th International Conference Vilnius Gediminas Technical University "Environmental Engineering”. DOI: https://doi.org/10.3846/ enviro.2017.214.

7. Leń P. 2018. An algorithm for selecting groups of factors for prioritization of land consolida- 
tion in rural areas. Computers and Electronics in Agriculture, 144, 216-221. DOI: 10.1016/j.compag.2017.12.014.

8. Mika M. 2016. Proposals for changes in surveying-legal procedures for the needs of cadastre in Poland. Reports on Geodesy and Geoinformatics, 102(1), 67-77.

9. Noga K. 2001. Metodyka programowania i realizacji prac scalenia i wymiany gruntów w ujęciu kompleksowym. Methodology of programming and execution of land consolidation and exchange works in the complex attitude (in Polish). Szkoła Wiedzy o Terenie, Kraków.

10. Pluta W. 1986. Multidimensional comparative analysis in econometric modeling. PWN, Warszawa.

11. Stręk Z. 2017. Engineering for rural development analysis of demand for land consolidation in Milejów commune, Łęczna district. In: Proceedins of the Conference on Engineering For Rural Development, Jelgava, 24-26 May 2017, pp. 593-599, DOI: 10.22616/ERDev2017.16.N119.

12. Wójcik-Leń J., Sobolewska-Mikulska K., 2017 a. Specific features of development of selected agricultural problematic areas in the land consolidation process. Journal of Water and Land Development, No. 34, pp. 249-258. DOI: 10.1515/jwld-2017-0060.

13. Wójcik-Leń J., Sobolewska-Mikulska K., 2017 b. Issues related to marginal lands with reference to selected agricultural problematic areas. Journal of Water and Land Development, No. 35, pp. 265273. DOI: 10.1515/jwld-2017-0093.

14. Wójcik-Leń J., Stręk Ż., 2017. Proposal for land consolidation project solutions for selected problem areas. In: Proceedings of the World Multidisciplinary Earth Sciences Symposium (WMESS 2017). Earth and Environmental Science, 95, 032016. DOI: 10.1088/1755-1315/95/3/032016.

15. Żak M. 2006. Basics of geodetic control of agricultural land (in Polish). Akademia Rolnicza, Kraków.

16. Act 1982. Act of 26 March 1982 on Consolidation and Exchange of Land.

17. Regulation 2013. Regulation of the Minister of Administration and Digitization of 29 November 2013 amending the Regulation on the Registration of Land and Buildings.

18. RDP 2014, Rural Development Programme for 2014-2020. 